\title{
Responding to supply chain disruptions caused by the COVID-19 pandemic: A Black Swan event for omnichannel retailers
}

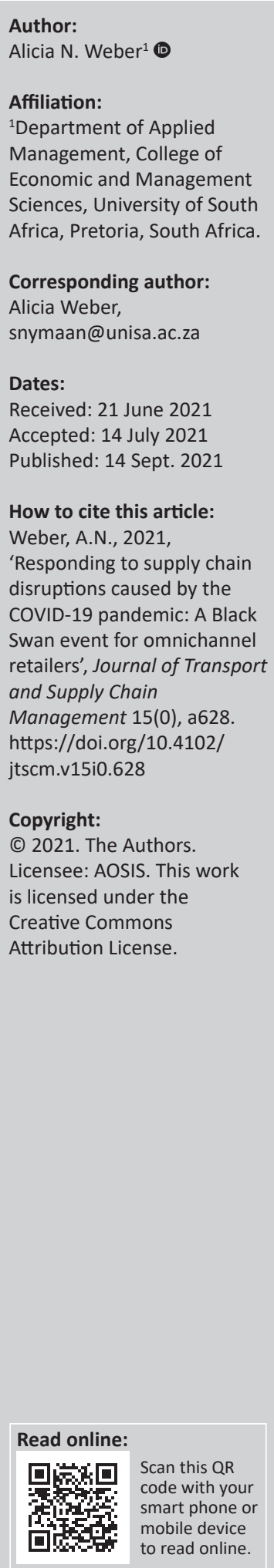

Background: The COVID-19 pandemic has triggered unprecedented growth in digital commerce and has accelerated the digital transformation of many retailers. An unforeseen event, such as the COVID-19 pandemic, is often referred to as a 'Black Swan' event - being of low probability to occur but causing substantial disruptions to a supply chain. Lockdown restrictions imposed to curb the spread of coronavirus resulted in significant external and internal disruptions to retailers' supply chains. Omnichannel retailer's ability to respond to the pandemic's disruption hinges on resilient supply chain strategies.

Objectives: This article explored the major supply chain disruptions experienced by South African omnichannel retailers because of the COVID-19 pandemic. Furthermore, it investigated the response strategies employed by the retailers as part of their efforts to mitigate the disruptions caused.

Method: This study followed a qualitative, exploratory research design. Data were collected through 17 semi-structured interviews with the senior managers from nine different large omnichannel retailers in South Africa.

Results: The study found that omnichannel retailers experienced external and internal supply chain disruptions during the pandemic. The most noticeable external disruption was the drastic migration of consumers to online channels and the retailers' inability to meet demand surges. Internally, systems constraints of both front- and back-end operations were identified as prominent disruptions. In response, the omnichannel retailers highlighted the importance of being agile to unlocking investments and scale capacity, to plan for the long-term, and to make strategic decisions, fluently.

Conclusion: This article adds to the body of knowledge by being one of the first empirical studies to explore the impact of the COVID-19 pandemic on omnichannel supply chains in South Africa. In addition, this article adds to the scarce publications on the impact a 'Black Swan' event such as the COVID-19 pandemic can have on supply chains and possible ways retailers can react to similar disruptions in future.

Keywords: COVID-19 pandemic; omnichannel; supply chain; supply chain disruption; supply chain agility; response strategies; coronavirus.

\section{Introduction}

On 30th of January 2020, the World Health Organization (WHO) declared the novel COVID-19 outbreak a public health emergency (World Health Organization 2020). In response, governments around the world enforced partial or total lockdowns (Ali, Rahman \& Frederico 2021). Lockdowns bring health benefits for a society in that it aids with the containment of the spread of a virus; however, lockdowns can cause irrevocable damage to an economy (Dohale et al. 2021). Worldwide lockdowns drastically altered people's lifestyles, livelihoods and how organisations traditionally operated (Schambach 2020). Ivanov (2021) reports that the magnitude and speed of the collapse in economic activity because of the widespread lockdowns are unlike anything experienced in recent times.

The COVID-19 pandemic has caused significant supply chain disruption (SCD) and has undoubtedly tested the ingenuity and resilience of supply chains globally (Magableh 2021:1). Supply chain disruptions relate to unplanned and unanticipated events that disrupt the normal flow of goods and materials within the supply chain (Craighead et al. 2007:131). Although supply chain management (SCM) researchers have investigated and described various effective strategies 
in response to SCDs, the COVID-19 pandemic threw many firmly held assumptions about SCD strategies into disarray (Flynn et al. 2021:3). Essentially, the pandemic has illuminated blind spots within some of the most sophisticated risk and disruption management strategies, exposing their weaknesses and instabilities (Magableh 2021:3). Ultimately, the pandemic has highlighted a need for organisations to accelerate agile ways of working and building more resilient supply chain operations (Van Hoek 2020:342).

Extant research suggests that resiliency is an effective way to manage risk and recover from SCDs (Adobor 2019:543; Macdonald et al. 2018:4341; Ponomarov \& Holcomb 2009:125). However, the pandemic is considered a new super-disruptor, or so-called 'Black Swan' event, raising novel questions and decision-making contexts beyond the traditional understanding of supply chain resilience (Magableh 2021:13; Wieland \& Durach 2021:1). The concept of 'Black Swan' event was first coined by Taleb (2007) in a book of the same name. Herein, the author described 'Black Swan' events as instances with a high impact but with a low probability of occurring. Although 'Black Swan' events are rare, the frequency of these events is on the rise. For example, in the last year alone, supply chain managers were faced with two such events, namely, the COVID-19 pandemic and the obstruction of the Suez Canal in March 2021. According to Wieland and Durach (2021:1), anecdotal evidence suggests that 'Black Swan' events cause the most disruption to a supply chain because such events are overlooked and not planned for, resulting in reactive responses to these disruptions instead of proactive planning.

Magableh (2021:13) debate that the COVID-19 pandemic is different from other 'Black Swan' events as it simultaneously disrupted both demand and supply. Supply disruptions originated from delays in delivering certain raw materials and imports, whilst demand was disrupted because of the sudden changes in consumer lifestyles, which wholly altered consumers' way of living, working and shopping (Halan 2021). Indeed, traditional SCD planning, mitigation, and recovery strategies were insufficient in responding to the mega disruptions caused by the COVID-19 pandemic (Paul \& Chowdhury 2020:284). Accordingly, organisations have shifted towards survival and adaptation strategies because stabilising to or achieving an 'old normality' is no longer possible as the 'old equilibrium' no longer exists (Mollenkopf, Ozanne \& Stolze 2021:192; Sarkis 2021:68; Schleper et al. 2021:202).

Whilst omnichannel retailing was not born out of the COVID-19 pandemic, the global health crisis has dramatically propelled consumers' use of digital shopping channels. Omnichannel retailing allows customers the option of moving seamlessly between fully integrated frontend operations (different physical and digital channels) as well as back-end operations (different order fulfilment and last-mile delivery options) (Picot-Coupey, Huré \& Piveteau 2016:337). Nielsen (2020a) reports that, across consumer groups, digital shopping channels have become the most critical shopping resources for constrained consumers. However, not only customers were constrained during the pandemic, Ürgüplü and Hüseyinoğlu (2021) found that with the advent of the pandemic and its accompanying lockdown restrictions, many offline retailers were also forced to transform towards digital retailing as a means to continue trading. Whilst offline retailers were still sceptical about the future scale of online retail, retailers with omnichannel capabilities have come to truly appreciate the competitive advantage of such services in turbulent times (Kazancoglu \& Demir 2021).

Although omnichannel shopping may be convenient for the consumer, it is no simple matter on the retailer's end. Even before the COVID-19 outbreak, South African retailers struggled to streamline their supply chains to facilitate online shopping. As a result of the pandemic, however, retailers are now struggling to boost their online capacity to match shopper traffic and maintain their ability to fulfil customer demand. Demand spikes for online orders necessitate omnichannel infrastructure in front-end operations such as their website and mobile applications and back-end operations such as order fulfilment and last-mile delivery options. However, developing these omnichannel infrastructures in a short time is challenging because it requires changes to complex organisational structures and processes (Rai et al. 2019:268).

To set the scene for this article, the author takes an unconventional approach by quoting one of the participant's accounts of the impact the COVID-19 pandemic has had on their 'normal' omnichannel supply chain operations. This quotation aims to illustrate the many difficulties the omnichannel retailers in South Africa experienced during the pandemic and to provide a preface for the issues addressed throughout this article:

'COVID has pushed us about 3-5 years ahead of the planned trajectory, so that's nice, but it's come with a lot of pain. So, where it's nice that everyone's buying online, the infrastructure in the background... it's all breaking beneath the surface. So, you're like a duck in water. You look great from the top but at the bottom you're scurrying like hell because you're tryna make it work. So, that's really what happened. Not only have we broken our systems but we broke the couriers, we broke the airlines, everything broke. And I think that's taught us a major lesson, I don't think we could have planned it. It's about how we reacted to it.' (Participant 5, Head of Transport and Engineering Logistics, 24 years of experience)

\section{Purpose}

The pandemic's impact on global supply chains has been drastic (Butt 2021) - revealing that most supply chains were insufficiently resilient when faced with multiple and multidirectional concurrent changes in supply and demand (Ketchen \& Craighead 2021:51). Whilst some supply chains have broken down almost entirely, others have responded to the crisis in such a way that they have emerged more robust than ever before (Flynn et al. 2021:5). The pandemic itself and 
the ways in which organisations have responded to it, offer opportunities to diversify the understanding of SCD and resilience.

This article adds to the body of knowledge by being one of the first empirical studies to explore the impact of COVID-19 on omnichannel supply chains in South Africa. By doing so, this article answers the call of a handful of researchers who have investigated the impact of COVID-19 on various supply chains issues. Some of the relevant papers call for supply chain scholars to delve deeper into the phenomenon to explore valuable lessons learnt (Flynn et al. 2021:5), particularly the impact of the pandemic on both the up-anddown streams of the supply chain (Butt 2021). Additionally, these researchers also called for scholars to investigate the strategies employed by organisations to reduce the severity of the pandemic's disruption on supply chains (Free \& Hecimovic 2021:75). Finally, Ivanov (2021) called on scholars to investigate the interplay between agility and resilience in response to the disruption. This article aimed to address these issues from the perspective of omnichannel retailers in South Africa. Therefore, this article's purpose was to uncover the major SCDs South African omnichannel retailers experienced because of the COVID-19 pandemic, as well as to explore the response strategies employed by retailers in reaction to the SCD caused. The following two research questions (RQs) guided this research:

- RQ1: What were the major supply chain disruptions omnichannel retailers in South Africa faced during the COVID-19 pandemic?

- RQ2: What response strategies did South African omnichannel retailers employ to react to the supply chain disruption caused by the COVID-19 pandemic?

\section{Literature review \\ Omnichannel retailing}

Omnichannel retailing refers to a multichannel sales approach from a retailer who seeks to provide customers with a seamless shopping experience regardless of the channel or touchpoint the consumer use. Huré, Picot-Coupey and Ackermann (2017:321) found that customers equate 'seamlessness' to the ability to use channels interchangeably and that customers expect both content (information) and process consistency across all channels. Omnichannel retailing differs from previous forms of retailing, such as multichannel retailing. With multichannel retailing, channels are operated as separate business units 'working in silos' where omnichannel retailing takes an integrated approach to channel management. Kourimsky and Van Den Berk (2014:6) debate that omnichannel retailing is not merely an evolution of multichannel retailing but represents an entirely different approach to commerce. With multichannel retailing, the focus is on optimising sales activities within each channel, whilst with omnichannel retailing, the focus is on optimising sales by addressing customers' specific requirements and lifestyles to create a unique, complete and seamless customer experience (Juaneda-Ayensa, Mosquera \& Murillo 2016:1).
Omnichannel retailers face many supply chain complexities, most of which consumers are not privy to (Newstore 2020:23). In actuality, a consumer has no appreciation for any process after the 'buy now' point. In the mind of the consumers, they can visualise the product arriving at their door, and they expect the delivery to be 'anytime now' or for the order to be ready for collection 'very soon' (Snyman 2014:177). However, in reality, once a customer has placed an order, several variables such as availability of staff and sufficient inventory need to fall into place to fulfil the order (Peinkofer et al. 2019:3613). Accordingly, omnichannel supply chains require fully integrated front-end operations (different physical and digital channels and touchpoints) as well as backend operations (different order fulfilment and last-mile distribution channels) to succeed (Picot-Coupey et al. 2016:337). These channel integration efforts add a 'layer of complexity' to the supply chain (Murfield et al. 2017; Saghiri et al. 2017; Song, Song \& Sun 2019).

\section{Front-end and back-end supply chain operations in omni-channel retailing}

From a supply chain perspective, omnichannel retailing is concerned with integrating two domains: firstly, front-end operations, and secondly, back-end operations. Integrated front-end operations offer customers the ability to seamlessly move between the retailer's different physical (e.g. bricksand-mortar) and digital channels (e.g. website or mobile application). Mirsch, Lehrer and Jung (2016:2) report that most customers use both physical and digital channels along the customer journey. These customers switch between channels and use multiple channels in tandem whilst shopping, for example, using their mobile phone to compare prices whilst in a brick-and-mortar store. Kembro, Norrman and Eriksson (2018:898) debate that in a truly omnichannel world, once a customer has placed their order via one of the retailer's front-end channels, they would be offered an array of different last-mile (back-end) fulfilment options to complete their shopping journey.

Integrated back-end operations comprise manifold issues. Hübner, Kuhn and Wollenburg (2016) developed a comprehensive strategic planning framework outlining the characteristics and design parameters for back-end operations in omnichannel retailing. These authors observed that backend operations comprise two supply chain design parameters, that is, back-end fulfilment and last-mile distribution. Backend fulfilment refers to the picking location of the order (e.g. fulfilment centre, manufacturer site, or retail store) as well as the level of automation in the fulfilment process. Last-mile distribution, in its own right, comprises various design issues, that is, delivery mode (home delivery or in-store collection), delivery velocity (same-day, next-day, more than 2 days), delivery time (specific delivery time slot or undefined delivery time), delivery area (local to international), and the process of handling product returns (Hübner et al. 2016:234; Marchet et al. 2018:450). In addition to these supply chain design decisions, retailers also need to determine if any of these processes will be outsourced to specialised third-party logistics providers (3PLs) with the ability to offer a 
comprehensive and sophisticated service, or if the entire lastmile distribution process will be managed in-house (Rai et al. 2019:268).

\section{The effect of COVID-19 pandemic on omnichannel retailing}

Before the pandemic, the adoption of online retail in South Africa was slow. Weber and Badenhorst-Weiss (2018:3) explain that South Africa has a large poor (often unemployed) population living in underdeveloped rural areas with little access to resources, the Internet and infrastructure and that these challenges restricted many South Africans from shopping online. However, the year 2020 and the COVID-19 pandemic earmarked a global 'retail revolution' (Deliotte 2020; Haines 2020; Nielsen 2020b) - changing how retail supply chains traditionally operated and how customers shopped. In addition, Nielsen (2020b) reports that even as lockdown restrictions started to ease, many consumers substantially reduced their physical shopping excursions, opting for risk-averse alternatives, such as those found online.

Whilst global government-imposed lockdown restrictions may have catapulted digital commerce forward by at least 5 years (Bresler 2020), it has resulted in significant demand and supply disruptions. Demand was affected because of the drastic changes in consumer behaviour (Free \& Hecimovic 2021:72; Magableh 2021:5). Panic buying from customers emptied supermarket shelves of essential products such as toilet paper, pasta, infant formula, and diapers (Harland 2021:72). Retailers with online channels reported unprecedented demand for online shopping and home delivery options (Mahajan \& Tomar 2021:37). The sudden demand for online retail points to an interesting shift in consumer behaviour. Although a lack of trust in the online shopping process has often been listed as one of the biggest obstacles for consumers to transacting online (Hossain et al. 2020:237; Zhang et al. 2018:182), during the pandemic, the perceived health risk of visiting a physical retail store outweighed other perceived risks of digital retail (such as not receiving products or the threat of paying for products online). Hence, consumers not only started to trust digital forms of retail but, during lockdown periods, also depended on online shopping for their most basic needs (Bell 2020). For those retailers whose online orders have skyrocketed, the increase came with an amplitude of challenges. Some of the challenges included limited digital commerce capabilities and inadequate omnichannel retailing readiness and resources, particularly in logistics, digital order fulfilment, mobile applications, supply chain (partner) capacity and payment options for unbanked consumers (Deloitte 2020).

As stated above, not only demand was affected by the pandemic, but also supply. Limitations imposed on imports and exports, mainly imports from China, saw many supply chains come to a standstill (Ali et al. 2021). China is often referred to as 'The World's Factory', arguably then, when the world's factory was placed under lockdown, the ripple effects could be seen (and felt) worldwide (Bajpai 2020; Thompson \& Anderson 2021:159). Supply disruptions have been described as crippling for an organisation's operations (Vermeulen, Niemann and Kotzé 2019:24), affecting operational, financial, and strategic performance (Craighead et al. 2007:132; Macdonald et al. 2018:4337). The USA based Institute for Supply Management (2021:5) reports that lead times for imports from China has increased by $102 \%$ globally; consequently, organisations are holding more inventory to mitigate the risk of stock-outs. However, such mitigation strategies can serve as a significant cost drain for retailers, and alternative response strategies should be investigated to reduce cost and improve recovery time (Harland 2021:33).

\section{The COVID-19 pandemic and South African retail supply chains}

In South Africa, a 6-week national lockdown was enforced between March and April 2020. The lockdown resulted in an unprecedented change in South African consumers' shopping behaviour, with World Wide Worx (2021) reporting that $68 \%$ of South African consumers indicating that they were shopping more online since the onset of the pandemic. Demand hikes were deeply rooted in product categories (i.e. non-essential versus essential products), with Hartzenberg (2020) reporting that South African grocery stores (with digital shopping platforms) experienced a 357\% increase in online sales during the lockdown period. Additionally, the payment platform, PayFast, reported a 226\% year-on-year increase in new business account registrations as many local retailers pivoted their service offering to provide e-commerce options to continue trading during the lockdown (Hartzenberg 2020).

\section{Supply chain disruption management}

As stated during the introduction, SCDs disturb the normal operations of an organisation and can severely affect an organisation's reputation and customer confidence (Agigi, Niemann \& Kotzé 2016:4), its financial well-being (Nel, De Goede \& Niemann 2018:3) and its operational capability (Thompson \& Anderson 2021:168). Supply chain disruptions can originate either from an external SCD or an internal SCD. External SCDs relate to factors outside an organisation's control, for example, natural and environmental disasters, government regulations, price fluctuations, and geopolitical disruptions (Pettit, Fiksel \& Croxton 2010:11). On the other hand, internal SCDs originate within an organisation's operational walls, for example, changes in management, machine breakdowns, strikes, and product recalls (Agigi et al. 2016:3).

Supply chain disruption management comprises four cycles, namely, disruption detection, disruption reaction, disruption recovery, and disruption learning (Behdani 2013:13). Disruption detection entails detecting and locating an SCD and determining its expected consequences as quickly as possible (Nel et al. 2018:4). Disruption reaction relates to an organisation's ability to assemble a multidisciplinary team to develop a reaction plan in 
response to the disruption (Behdani 2013:40). Disruption recovery is initiated when preventative measures and reactive plans were unable to mitigate the SCD sufficiently. During disruption recovery, organisations use information on the cause and effect of disruptions to develop response strategies (Messina, Barros \& Matopoulos 2020:439). Disruption learning in the final part of the SCD management cycle, means that organisations note lessons learnt from the disruption and make the appropriate changes to plans and policies (Behdani 2013:41).

To date, only a limited number of studies have explored the ways in which organisations can mitigate the impact of SCDs caused by the COVID-19 pandemic (Butt 2021; Dohale et al. 2021; El Baz and Ruel 2021; Mahajan \& Tomar 2021). Dohale et al. (2021) and Mahajan and Tomar (2021) conducted extensive literature reviews to recontextualise previously identified SCDs within the context of the COVID-19 pandemic. Butt (2021) conducted a qualitative study to explore importing disruptions experience by manufacturing organisations, whilst El Baz and Ruel (2021) investigated the role of risk-mitigating strategies in French firms' responses to the pandemic. Although these researchers took different perspectives on the pandemic's impact on supply chains, a dominant theme that emerged from the research of these scholars was that supply chain resilience is critical to recovering from the pandemic.

\section{Supply chain resilience}

Supply chain resilience is considered both a safe and tactical weapon in response to SCDs (Mittal \& Sinha 2021). Recently, authors have started to critique the different interpretations of resilience (Wieland \& Durach 2021:2). Most notably, the ecologist Holling (1996) distinguished between engineering resilience and ecological resilience. Holling (1996) suggested that engineering resilience relates to reliable and stable systems such as those found within the engineering field. Engineering resilience means that there is one equilibrium (or stable state) and that resilience relates to a system's ability to 'bounce back' to a pre-disruption equilibrium (Novak, Wu \& Dooley 2021:3). Ecological resilience refers to an organism's (within a business sense an organisation's) ability to persist and adapt to an alternative 'steady state' following a disruption (Adobor 2019:536). Wieland (2021:62) distinguishes between engineering and ecological resilience by observing that in the former, resilience is measured through a system's resistance to disturbances or 'the speed with which a system returns to its equilibrium', with the latter resilience is measured by the 'magnitude of disturbance the system can absorb before it changes its structure'. Wieland (2021:62), however, argues that within the scope of SCM, the concept of social-ecological resilience would be more suited. The author debates that both previous resilience perspectives (i.e. engineering and ecological resilience) fail to consider the social actors that inherently contribute to threats and solutions in the system. Wieland and Durach (2021) explain this reasoning by arguing that
[T] he emphasis on bouncing back as in engineering resilience or even bouncing forth, as in ecological resilience, fails to consider disturbance as a 'window of opportunity' for transforming to a radically different and more desirable trajectory. (p. 2)

Wieland (2021:64) describes how the pandemic has challenged organisations to rethink their supply chains and seize new supply chain opportunities. For example, the automakers such as Ford, General Motors, and Tesla morphed into de facto ventilator manufacturers and distributors to keep their operations running during lockdown restrictions. In line with the above discussion, this article follows Wieland and Durach (2021:2) definition of supply chain resilience, that is, 'the capacity of a supply chain to persist, adapt, or transform in the face of change'.

Accordingly, supply chain response and recovery strategies have been brought to the forefront for many organisations (Flynn et al. 2021:3). Consequently, supply chain resilience strategies are advocated to remedy the disruption caused by COVID-19 (Frederico 2021; Schleper et al. 2021:196; Thompson \& Anderson 2021:167).

\section{Supply chain resilience capabilities}

Being resilient and quickly adapting to disruptions are vital for an organisation's supply chain. Several capabilities have been investigated as antecedents to supply chain resilience. Table 1 summarises some of the most cited capabilities outlined by previous authors.

The COVID-19 pandemic has introduced an unprecedented and extraordinary situation for supply chain resilience, during which supply chain survivability requires immense resilience capabilities (Magableh 2021:3). Flynn et al. (2021:4) observed that because the impact of COVID-19 moved far beyond affecting a limited number of supply chains for a finite period, there is a need for a new way of managing supply chains to deal with extreme conditions that simultaneously addresses demand uncertainty, supply uncertainty and channel instability.

\section{Methods \\ Research design}

This study followed a qualitative, exploratory research design. The main advantage of a qualitative, exploratory research design is its flexibility (Cassell, Cunliffe \& Grandy 2018:474; Zikmund et al. 2013:65). Saunders, Lewis and Thornhill (2020:140) reinforce the advantage of flexibility in qualitative research by arguing that flexibility does not indicate an absence of direction to the enquiry but rather that the study's focus is initially broad and becomes progressively narrower as the research progresses. Because there is a dearth of published research on the impact of the COVID-19 pandemic on supply chains, the flexibility of a qualitative exploratory research design would aid the researcher in gathering multiple perspectives from participants with the aim of building a comprehensive picture of the topic under investigation. 
TABLE 1: Supply chain resilience capabilities.

\begin{tabular}{|c|c|c|}
\hline Variable & Description & Authors \\
\hline Flexibility & $\begin{array}{l}\text { Flexibility is the ability to change } \\
\text { positions to respond to an abnormal } \\
\text { situation better and to quickly adapt } \\
\text { to significant changes in the supply } \\
\text { chain. Flexibility can be achieved by } \\
\text { having multiple interchangeable } \\
\text { resources. }\end{array}$ & $\begin{array}{l}\text { Ponomarov and Holcomb } \\
\text { (2009:13); Pettit et al. } \\
(2010: 19) ; \text { Behdani } \\
\text { (2013:64); Simba et al. } \\
\text { (2013:3); Tukamuhabwa } \\
\text { et al. (2015:5592); Agigi } \\
\text { et al. (2016:4); Magableh } \\
\text { (2021:3); Negri et al. } \\
\text { (2021:6); Thompson and } \\
\text { Anderson (2021:168) }\end{array}$ \\
\hline Redundancy & $\begin{array}{l}\text { Redundancy focuses on limiting risks } \\
\text { and their consequences. Redundancy } \\
\text { can be achieved by keeping reserves } \\
\text { such as safety stock and sourcing } \\
\text { from multiple suppliers. However, } \\
\text { redundancy as a resilience capability } \\
\text { is often critiqued as a costly option } \\
\text { because the additional stock is } \\
\text { only used when unanticipated } \\
\text { events occur. }\end{array}$ & $\begin{array}{l}\text { Ponomarov and Holcomb } \\
\text { (2009:13); Pettit et al. } \\
(2010: 19) ; \text { Behdani } \\
(2013: 66) ; \text { Simba et al. } \\
\text { (2013:3); Tukamuhabwa } \\
\text { et al. (2015:5592); Agigi } \\
\text { et al. (2016:4); Free and } \\
\text { Hecimovic (2021:74); } \\
\text { Magableh (2021:3); Negri } \\
\text { et al. (2021:6); Thompson } \\
\text { and Anderson (2021:168) }\end{array}$ \\
\hline Visibility & $\begin{array}{l}\text { Visibility refers to the transparency } \\
\text { of an organisation's supply chain; it } \\
\text { requires an end-to-end view of the } \\
\text { entire supply chain and its } \\
\text { operating assets. }\end{array}$ & $\begin{array}{l}\text { Ponomarov and Holcomb } \\
\text { (2009: 13); Pettit et al. } \\
\text { (2010:19); Agigi et al. } \\
\text { (2016:4); Jain et al. } \\
\text { (2017:6793); Donadoni, } \\
\text { Caniato and Cagliano } \\
\text { (2018:300); Magableh } \\
\text { (2021:3) }\end{array}$ \\
\hline Collaboration & $\begin{array}{l}\text { Collaboration with other supply chain } \\
\text { entities ensures the exchange of } \\
\text { information between partners, } \\
\text { which reduces uncertainties and } \\
\text { complexities. }\end{array}$ & $\begin{array}{l}\text { Ponomarov and Holcomb } \\
\text { (2009:13); Pettit et al. } \\
\text { (2010:19); Simba et al. } \\
\text { (2013:3); Gunasekaran, } \\
\text { Subramanian and Rahman } \\
\text { (2015:6811); Tukamuhabwa } \\
\text { et al. (2015:5592); } \\
\text { Donadoni et al. (2018:300); } \\
\text { Vermeulen et al. (2019:8); } \\
\text { Magableh (2021:3) }\end{array}$ \\
\hline Agility & $\begin{array}{l}\text { Agility relates to the ability of an } \\
\text { organisation's supply chain to } \\
\text { respond quickly to unforeseen events } \\
\text { that result in changes to demand and/ } \\
\text { or supply. }\end{array}$ & $\begin{array}{l}\text { Ponomarov and Holcomb } \\
\text { (2009:13); Pettit et al. } \\
\text { (2010:4); Tukamuhabwa } \\
\text { et al. (2015:5592); Jain et al. } \\
\text { (2017:6793); Vermeulen } \\
\text { et al. (2019:7); Negri et al. } \\
\text { (2021:10) }\end{array}$ \\
\hline
\end{tabular}

Note: Please see the full reference list of the article, Weber A.N., 2021, 'Responding to supply chain disruptions caused by the COVID-19 pandemic: A Black Swan event fo omnichannel retailers', Journal of Transport and Supply Chain Management 15(0), a628. https://doi.org/10.4102/jtscm.v15i0.628 for more information.

\section{Sampling}

In qualitative research, sample selection profoundly affects the ultimate quality of the research (Coyne 1997:632). The unit of analysis for this study was omnichannel retailers in South Africa. Two cycles of purposive sampling were employed to recruit participants. Purposive sampling is described by Etikan, Musa and Alkassim (2016:2) as a sampling technique where a researcher deliberately chooses a participant because of the participant's qualities. In the first sampling cycle, purposive, experts sampling was employed. As the name suggests, expert sampling seeks the opinions of highly skilled or qualified individuals (experts) in a particular field (Etikan et al. 2016:3). Patton (2018:1) remarks that experts can provide valuable insights into the root of problems, their successes and failures, and future trends to watch. In this study, experts were identified based on three inclusion criteria for expert selection used in previous omnichannel and supply chain studies. These criteria included years of experience, management level and level of involvement with the phenomena under investigation. Table 2 provides an overview of the selection criteria and reference the original research which employed the criterion.
TABLE 2: Expert inclusion criteria used during participant identification.

\begin{tabular}{|c|c|c|}
\hline Expert criteria & Description & Reference \\
\hline Years of experience & $\begin{array}{l}\text { - A participant should have } \\
\text { at least } 10 \text { years of } \\
\text { experience managing retail } \\
\text { supply chains or supply } \\
\text { chain-related operations. }\end{array}$ & Reyes and Giachetti (2010) \\
\hline Management-level & $\begin{array}{l}\text { - A participant should hold } \\
\text { a top-management position } \\
\text { within their organisation. }\end{array}$ & $\begin{array}{l}\text { Hübner, Holzapfel and Kuhn } \\
\text { (2016:2690); Hosseini, } \\
\text { Röglinger and Schmied } \\
\text { (2017:5) }\end{array}$ \\
\hline $\begin{array}{l}\text { Level of involvement } \\
\text { with the phenomena } \\
\text { under investigation }\end{array}$ & $\begin{array}{l}\text { - A participant should be } \\
\text { directly involved in } \\
\text { managing one or more of } \\
\text { their organisation's } \\
\text { omnichannel supply chain } \\
\text { processes. }\end{array}$ & Rai et al. (2019:273) \\
\hline
\end{tabular}

Note: Please see the full reference list of the article, Weber A.N., 2021, 'Responding to supply chain disruptions caused by the COVID-19 pandemic: A Black Swan event fo omnichannel retailers', Journal of Transport and Supply Chain Management 15(0), a628. https://doi.org/10.4102/jtscm.v15i0.628 for more information.

TABLE 3: Participants' profiles.

\begin{tabular}{|c|c|c|c|c|}
\hline $\begin{array}{l}\text { Participant } \\
\text { number }\end{array}$ & Job title & Retailer & $\begin{array}{c}\text { Years of } \\
\text { experience }\end{array}$ & $\begin{array}{c}\text { Duration of } \\
\text { interview ( } \mathrm{min})\end{array}$ \\
\hline P1 & $\begin{array}{l}\text { Head of Logistics and } \\
\text { Supply Chain }\end{array}$ & Retailer A & 15 & 69.05 \\
\hline P2 & $\begin{array}{l}\text { Head of Logistics and } \\
\text { Facilities Management }\end{array}$ & Retailer E & 23 & 32.32 \\
\hline P3 & $\begin{array}{l}\text { Head of Logistics and } \\
\text { E-fulfilment }\end{array}$ & Retailer $\mathrm{E}$ & 25 & 95.37 \\
\hline P4 & Head of Logistics & Retailer $\mathrm{H}$ & 21 & 48.01 \\
\hline P5 & $\begin{array}{l}\text { Head of Transport and } \\
\text { Engineering Logistics }\end{array}$ & Retailer $\mathrm{E}$ & 24 & 36.12 \\
\hline P6 & $\begin{array}{l}\text { VP of Supply Chain \& } \\
\text { eCommerce Operations }\end{array}$ & Retailer B & 17 & 58.20 \\
\hline P7 & $\begin{array}{l}\text { Operations Business } \\
\text { Development Manager }\end{array}$ & Retailer D & 23 & 38.01 \\
\hline P8 & Head of Retail Innovations & Retailer D & 25 & 32.12 \\
\hline P9 & Brand Manager - Africa & Retailer F & 18 & 39.15 \\
\hline P10 & Head of Africa Supply Chain & Retailer F & 20 & 46.27 \\
\hline P11 & $\begin{array}{l}\text { Director of Retail } \\
\text { Operations }\end{array}$ & Retailer A & 28 & 45.45 \\
\hline P12 & Chief Operations Officer & Retailer B & 32 & 43.00 \\
\hline P13 & Managing Director & Retailer D & 26 & 46.54 \\
\hline P14 & CEO & Retailer G & 30 & 57.06 \\
\hline P15 & $\begin{array}{l}\text { GM: Retail and Supply } \\
\text { Chain Operations }\end{array}$ & Retailer I & 16 & 48.11 \\
\hline P16 & Head of Online Operations & Retailer A & 30 & 84.59 \\
\hline P17 & $\begin{array}{l}\text { Head of Supply Chain } \\
\text { Optimisation }\end{array}$ & Retailer C & 13 & 34.24 \\
\hline - & Average & - & 22.7 & 50.21 \\
\hline
\end{tabular}

After concluding cycle one of sampling, six participants had agreed to an interview with the researcher. This research followed the guidelines of Francis et al. (2010:1235), who recommends $7-12$ interviews be conducted in a qualitative study to ensure thick interpretations of the data. In line with these recommendations, a sample size of six participants was deemed inefficient. This prompted sampling cycle two, that is, snowball sampling. According to Tustin et al. (2005:349), in snowball sampling, participants are first chosen according to judgement sampling, which entails that selected participants identify other members who will also meet the specific requirements of the study. Bairagi and Munot (2019:98) state that snowball sampling is most beneficial when research is conducted within a population of undocumented participants (e.g. no complete list of the population exists). Using snowball sampling, the researcher asked each of the six 
TABLE 4: Retailers' profiles.

\begin{tabular}{|c|c|c|c|c|c|c|c|}
\hline Pseudonym & Main retail category & $\begin{array}{l}\text { Number of } \\
\text { sub-brands owned } \\
\text { by the retailer }\end{array}$ & $\begin{array}{l}\text { Geographic } \\
\text { operations } \\
\text { (including } \\
\text { South Africa) }\end{array}$ & Turnover (in 2020) & Store footprint & $\begin{array}{l}\text { Number of } \\
\text { employees }\end{array}$ & $\begin{array}{c}\text { Reported growth in } \\
\text { online sales during } \\
2020 \dagger\end{array}$ \\
\hline Retailer A & $\begin{array}{l}\text { - Fashion } \\
\text { - Homeware } \\
\text { - Groceries }\end{array}$ & 8 & 14 & \pm R78 billion & \pm 1500 & \pm 45000 & $57 \%$ \\
\hline Retailer B & $\begin{array}{l}\text { - Groceries } \\
\text { - Liquor } \\
\text { - Electrical appliances } \\
\text { - Building materials }\end{array}$ & 8 & 13 & $\pm \mathrm{R} 94 \mathrm{bn}$ & \pm 450 & \pm 51000 & $59 \%$ \\
\hline Retailer C & $\begin{array}{l}\text { - Fashion } \\
\text { - Homeware }\end{array}$ & 6 & 3 & $\begin{array}{l}\text { Not publicly } \\
\text { available }\end{array}$ & \pm 300 & \pm 3000 & Not reported \\
\hline Retailer D & $\begin{array}{l}\text { - Fashion } \\
\text { - Homeware and furniture }\end{array}$ & 5 & 10 & $\pm \mathrm{R} 23 \mathrm{bn}$ & \pm 1400 & \pm 20000 & $25 \%$ \\
\hline Retailer E & $\begin{array}{l}\text { - Fashion } \\
\text { - Homeware and furniture }\end{array}$ & 21 & 32 & $\pm \mathrm{R} 38 \mathrm{bn}$ & \pm 2700 & \pm 23000 & $48 \%$ \\
\hline Retailer F & $\begin{array}{l}\text { - Fashion } \\
\text { - Stationery }\end{array}$ & 8 & 20 & $\begin{array}{l}\text { Not publicly } \\
\text { available }\end{array}$ & \pm 170 & \pm 22000 & Not reported \\
\hline Retailer G & - Building materials and DIY & 8 & 9 & $\pm \mathrm{R} 9 \mathrm{bn}$ & \pm 200 & \pm 2700 & $18 \%$ \\
\hline Retailer H & $\begin{array}{l}\text { - Pharmaceutical } \\
\text { - Fashion }\end{array}$ & 5 & 5 & $\pm \mathrm{R} 34 \mathrm{bn}$ & \pm 900 & \pm 15600 & $191 \%$ \\
\hline Retailer I & $\begin{array}{l}\text { - Groceries } \\
\text { - Liquor } \\
\text { - Homeware and furniture } \\
\text { Pharmaceutical }\end{array}$ & 13 & 15 & $\pm \mathrm{R} 160 \mathrm{bn}$ & \pm 2400 & \pm 140000 & $368 \%$ \\
\hline
\end{tabular}

DIY, do-it-yourself; bn, billion.

$\dagger$, Where online growth was reported based on different retail divisions, the average growth increase across divisions were calculated.

interviewees to identify other colleagues within their network who met the expert criteria listed as part of cycle one of participant selection. During sampling cycle two, an additional 11 participants agreed to participate in the study. In total, the researcher conducted 17 virtual interviews amongst participants from nine different retailers representing all major retailing categories. Data saturation (whereby no new insights are obtained, and the researcher notices a 'repetition of responses' [Braun \& Clarke 2021b:203]) occurred on the 15th interview conducted in this study. Participant and retailer profiles are presented in Tables 3 and 4 , respectively.

\section{Data collection}

Following the literature review, a semi-structured interview protocol was developed. In line with COVID-19 restrictions, interviews were conducted virtually during February and March 2021 by the researcher. Participants were invited to participate in the study in one of three ways. Firstly, The Professional Body of Supply Chain Managers in South Africa (SAPICS) distributed an invitation to all their members. Secondly, the researcher identified (and invited) participants on the business-oriented social media platform, LinkedIn. Finally, as part of the snowball sampling process outlined above, interviewees identified other potential participants and referred them to the researcher. Once a participant agreed to an interview, an interview date was scheduled, and a virtual meeting link was created via any of the participants preferred telecommunication platforms (e.g. Skype, Zoom, MS Teams and Blue Jeans). Prior to the scheduled interview, the researcher sent each interviewee the informed consent form and the interview protocol. All participants agreed to have the meeting recorded for quality and transcription processes, albeit the researcher agreed to comply with the anonymity guidelines agreed upon before the interview.
Each interview started with an introduction to the study and lasted on average for about $50 \mathrm{~min}$. The researcher employed the services of a professional touch-typist to transcribe the audio. The $854 \mathrm{~min}(14.2 \mathrm{~h})$ of interview audio were transcribed to 324 pages of text. The researcher checked and compared the transcriptions with the audio to ensure their accuracy. Any transcription errors were corrected.

\section{Data analysis}

Reflexive thematic analysis (TA) was applied to analyse the data. Thematic analysis is defined by Clarke and Braun (2017:297) as a qualitative data analysis method '... for identifying, analysing, and interpreting patterns of meaning ("themes") within qualitative data'. This study followed the reflexive TA approach, which involves themes being developed from codes and conceptualised as patterns of shared meaning underpinned by a central organising concept. Theme development requires considerable analytic and interpretative work to illuminate the implicit or latent meanings captured within the data (Braun \& Clarke 2021a:39). Reflexive TA requires researchers to go beyond surface meanings to make sense of the data and tell a rich and compelling story (Braun \& Clarke 2006:95).

The researcher employed the qualitative data analysis programme ATLAS.ti to analyse the research and followed the six sequential steps of reflexive TA outlined by the proponents of the reflexive TA method, Braun and Clarke (2006:95). The six steps are familiarisation with the data, generating initial codes, searching for themes, defining and naming themes and producing the report. Hence, after the researcher had read and re-read the data corpus (entire data set), codes were compiled. The codes were then analysed to merge codes with similar meanings or to split large codes into smaller sub-sections. From the revised codes list, themes 


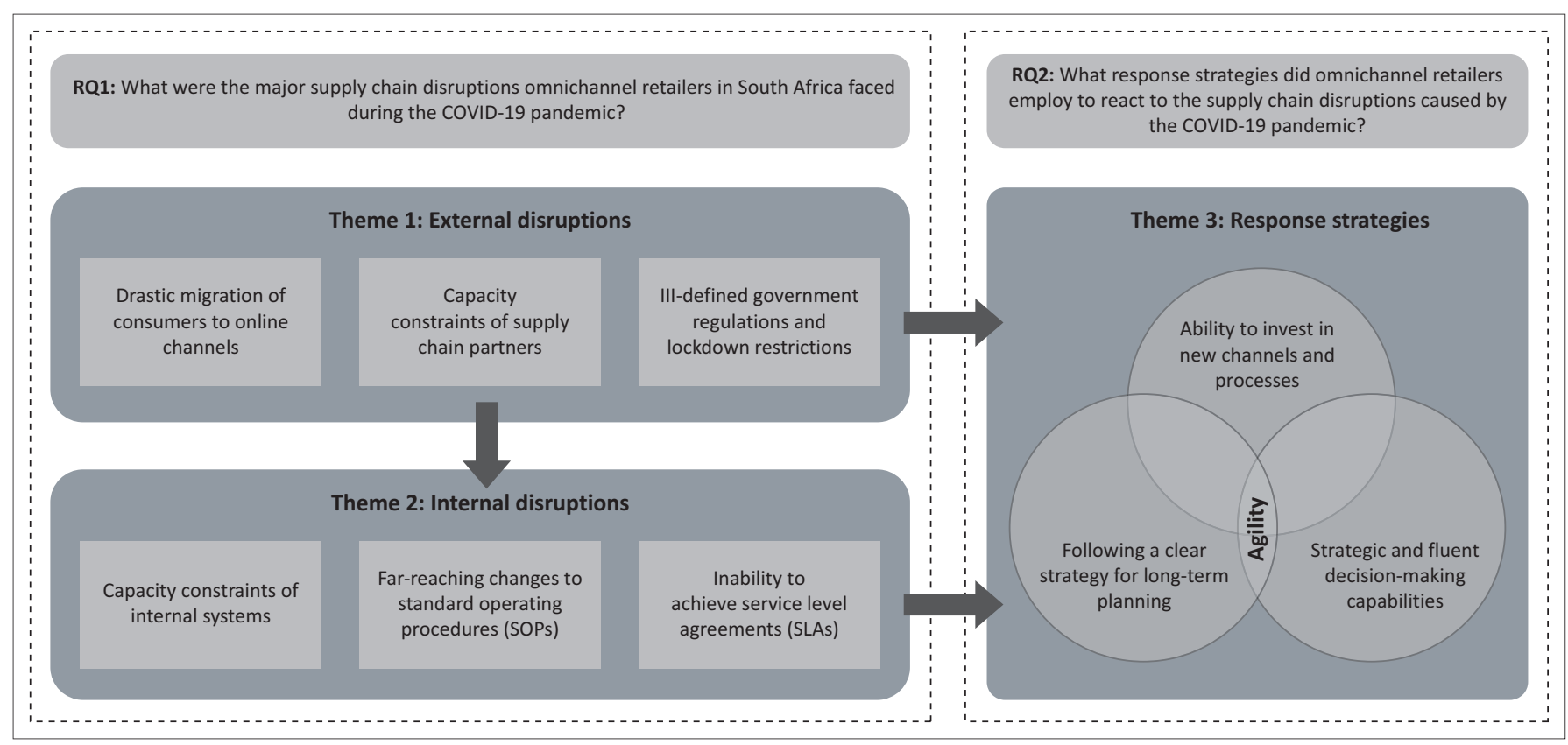

$R Q$ s, research questions.

FIGURE 1: Summary of themes and subthemes.

were developed. These themes were then re-evaluated based on their relevance within the context of the study, and final changes were made.

\section{Trustworthiness}

Frequently, qualitative research is evaluated against criteria suitable to quantitative research in terms of reliability and validity and is found to be deficient. Qualitative researchers argue that, because of the difference in nature and purpose of quantitative and qualitative research, it is flawed to apply the same criteria for trustworthiness or merit (Weber \& Badenhorst-Weiss 2016). The researcher practised several techniques, previously proposed as best practice, to ensure the trustworthiness of the research. Firstly, selecting participants who possess knowledge relevant to the study can signal trustworthiness (Lundberg, Nguyen \& Esparza 2019:23). The researcher constructed the 'expert criteria' to ensure that knowledgeable participants were included in the study. Secondly, all interviews were audio-recorded, transcribed by a specialist transcriber, and rechecked by the researcher. Thirdly, whilst conducting the interviews, the researcher applied iterative questioning through probes, which allowed the researchers to elicit detailed answers from participants. Fourthly, a 'rich, thick description' of the phenomena under investigation, the participants and methods used were provided in the proceeding sections of this article (Creswell \& Creswell 2017:270). Fifthly, an audit trail (keeping a stepwise account of the procedures followed) was kept in terms of the methodology and reflexive TA process followed. Finally, as Lapan, Quartaroli and Riemer (2012:29) suggest, the researcher provides a chain of evidence in the results section so that the reader can see the source of a conclusion/finding in the form of verbatim quotes from the participants.

\section{Ethical considerations}

The institutional ${ }^{1}$ Research Ethics Committee approved this study. Before the interviews were conducted, all the participants were supplied with a participant information sheet and asked to sign the informed consent form. The consent form explained the purpose of the study and emphasised that participation in the study was voluntary. To comply with the condition of anonymity, each retailer and participant was assigned a letter of the alphabet as its fictitious name. Consequently, personal details concerning participants (interviewees) are omitted from the study.

\section{Results}

The analysis below identifies and discuss the three main themes were constructed from the data, that is, external SCDs (Theme 1), internal SCDs (Theme 2) and response strategies (Theme 3) employed by omnichannel retailers to mitigate disruptions caused by the pandemic. These themes were derived from a frequency table (Table 5) that quantified the number of times a participant mentioned each code. From these codes, themes and sub-themes were developed.

Three main themes (external disruptions, internal disruptions and response strategies) were identified from the data analysis, each supplemented by sub-themes. Figure 1 illustrates the link between the main themes, sub-themes and the RQs. Each theme is discussed below, and relevant evidence from the data supplements the discussion.

\section{Theme 1: External disruptions}

Theme 1, external disruptions relate to SCDs omnichannel retailers faced because of the COVID-19 pandemic that 1.The institution where the researcher is employed. 
TABLE 5: Frequency table of codes.

\begin{tabular}{|c|c|c|c|c|c|c|c|c|c|c|c|c|c|c|c|c|c|c|c|}
\hline Code & Theme classification & P1 & P2 & P3 & P4 & P5 & P6 & P7 & P8 & P9 & P10 & P11 & P12 & P13 & P14 & P15 & P16 & P17 & Total \\
\hline $\begin{array}{l}\text { Drastic migration of } \\
\text { consumers to online } \\
\text { channels }\end{array}$ & External disruption & 1 & 1 & 1 & 1 & 1 & 1 & 1 & 1 & 1 & 1 & 1 & 1 & 1 & 1 & 1 & 1 & 1 & 17 \\
\hline $\begin{array}{l}\text { Capacity constraints of } \\
\text { internal systems }\end{array}$ & Internal disruption & - & 1 & 1 & - & 1 & 1 & - & 1 & - & 1 & 1 & - & 1 & - & 1 & 1 & - & 10 \\
\hline $\begin{array}{l}\text { Capacity constraints of } \\
\text { supply chain partners }\end{array}$ & External disruption & 1 & - & 1 & 1 & 1 & 1 & - & - & 1 & - & 1 & - & - & 1 & - & - & 1 & 9 \\
\hline $\begin{array}{l}\text { Inability to achieve service } \\
\text { level agreements (SLAs) }\end{array}$ & Internal disruption & - & 1 & 1 & 1 & - & - & 1 & - & 1 & - & - & 1 & - & - & 1 & 1 & 1 & 9 \\
\hline $\begin{array}{l}\text { Following a clear strategy } \\
\text { for long-term planning }\end{array}$ & Response strategy & 1 & - & - & - & 1 & - & - & 1 & - & 1 & 1 & - & - & 1 & - & 1 & 1 & 8 \\
\hline $\begin{array}{l}\text { Strategic and fluent } \\
\text { decision-making capabilities }\end{array}$ & Response strategy & 1 & - & 1 & - & - & 1 & - & - & 1 & - & - & 1 & - & 1 & - & 1 & - & 7 \\
\hline $\begin{array}{l}\text { Ability to invest in new } \\
\text { channels and processes }\end{array}$ & Response strategy & - & 1 & - & 1 & - & - & - & - & - & 1 & - & 1 & - & 1 & - & 1 & - & 6 \\
\hline $\begin{array}{l}\text { Far-reaching changes to } \\
\text { standard operation } \\
\text { procedures (SOPs) }\end{array}$ & Internal disruption & 1 & - & 1 & - & 1 & - & - & - & 1 & - & - & 1 & - & - & - & 1 & - & 6 \\
\hline $\begin{array}{l}\text { III-defined government } \\
\text { regulations and lockdown } \\
\text { restrictions }\end{array}$ & External disruption & 1 & 1 & - & 1 & - & - & - & 1 & - & - & - & 1 & - & - & - & 1 & - & 6 \\
\hline
\end{tabular}

disrupted their 'normal' supply chain operations outside of their control. External disruptions comprise three sub-themes, namely, drastic migration of consumers to online channels, supply chain partners' capacity constraints, and ill-defined government regulations and lockdown restrictions. From the data analysis, it was also observed that the external SCDs consequently caused the internal SCDs.

\section{Drastic migration of consumers to online channels}

The pandemic has caused an unprecedented and unexpected surge in demand for certain products and services (Mahajan \& Tomar 2021:37; Paul \& Chowdhury 2020:284). Consumers' sudden and drastic migration to online channels was by far the biggest SCD experienced by omnichannel retailers participating in this study. This was also found in the study of Mollenkopf et al. (2021:194), who argue that because of the surge in demand for home delivery services, retailers had to adapt their order fulfilment processes and hire new employees. Employees also needed to be trained in order picking and home delivery, which was a challenging endeavour to uptake whilst maintaining social distancing protocols. Nevertheless, the participants viewed the surges in demand as both positive and negative. On the positive side, the participants indicated that the growth of the online channel had changed the minds of conservative members of personnel who were still unconvinced of the feasibility of online retailing in South Africa. These participants cited COVID-19 as a turning point for online retail in South Africa:

\footnotetext{
'... it's been a gamechanger for online... it's forced us to move much faster, which I'm pleased about because we now don't have to convince our colleagues that things have to change. So, the case for change was made by COVID. The numbers are so fundamental that you can't argue them, and they're factual.' (Participant 12, Chief Operations Officer, 32 years of experience)

'COVID was really good for us. It was hard but it was actually good for us... I think the e-commerce industry will never be the same again. We will reflect back on twenty-twenty in five or ten years' time and we'll realise that that was the point when e-commerce took off in the country, and everybody that hadn't
}

shopped online before was forced into shopping online.' (Participant 6, VP of Supply Chain \& eCommerce Operations, 17 years of experience)

The participants cited capacity constraints as the biggest SCDs because of the increase in demand for online channels. For example, before the outbreak of the pandemic, retailers were spending large amounts of money on advertising to try and increase demand for online retailing. However, during the pandemic, the retailers report that they were severely underprepared for the surge in demand. As a result, additional fulfilment channels such as click-and-collect had to be implemented to keep up with the rising demand surges whilst capacity development programmes were conceived and implemented:

'Very early in the COVID lockdown, overnight, in the space of twenty-four hours, we ran out of capacity in our foods channel... normally our next delivery date would be the next day. In the space of forty-eight hours, our next delivery date was two weeks out. The channel was full. We could only do so much to stretch it ... So, we had to find another way of working.' (Participant 16, Head of Online Operations, 30 years of experience)

\section{Capacity constraints of supply chain partners}

Capacity constraints of supply chain partners were a primary concern for many omnichannel retailers during the pandemic. Two issues concern the capacity constraints of supply chain partners. Firstly, the surging demand for online channels coincided with an increased demand for home deliveries (Mollenkopf et al. 2021:194). As a result, last-mile deliveries are often outsourced to 3PLs to create a more mature logistic service at a lower cost (Ye et al. 2018:669). However, scaling these services can take time. The participants expressed that the capacity constraints of their partners were prohibiting them from scaling their own operations to meet the surges in demand from customers. Additionally, the 3PLs were grappling with their own set of challenges, such as the cleaning of vehicles to adhere to COVID protocols or working on rotational rosters in warehouses to maintain social distancing protocols: 
It really tested our partners, pushing three to four times the volume through their facility than they did before, this would normally require a lot of upfront planning.' (Participant 11, Director of Retail Operations, 28 years of experience)

'... we've had to make agreements with our suppliers to hold much higher stock levels than ordinarily they would.' (Participant 4, Head of Logistics, 21 years of experience)

The reviewed literature observed that imports from China caused significant disruptions to global supply chains (Magableh 2021:5). This study's participants echoed this statement by indicating that import delays restricted them from keeping ultimate stock levels. As a result, alternative stock ordering and storing protocols were implemented to reduce the disruption caused:

'Imports obviously were a major restriction. That caused problems for us. Our sales of imported products is [sic] probably about ten percent of our volume, COVID delayed [imports] by a couple of months. It has an impact on our ability to replenish our stores.' (Participant 4, Head of Logistics, 21 years of experience)

\section{III-defined government regulations and lockdown restrictions}

The reaction of government institutes to combat the spread of the virus has impacted the operational capacity of supply chains and caused large-scale confusion amongst retailers (Thompson \& Anderson 2021:165). The participants indicated that because the government was faced with a never-seenbefore phenomenon, regulations and restrictions were implemented haphazardly, without considering the ripple effects of such restrictions on businesses. In particular, the participants highlighted how legislation on product restrictions created confusion, for example, some retailers were selling products that were marked as restricted by another retailer. In addition, lockdown restrictions were particularly disruptive on supply chains of products with shelf-life considerations (Mahajan \& Tomar 2021:37), for example, liquor products. For the retailers trading within these categories, spoilage and shrinkage was a significant concern. In many cases, the retailers were left with large amounts of stock and more stock scheduled for arrival without the ability to trade, which impacted their cash flow and storage capacity:

'... in the harsh lockdown we actually had to close down for six weeks, so it had a massive impact on trading and supply chain. So, we had all the stock and the stock that was coming from suppliers was coming... we chose to pay our suppliers, so it had a big cashflow impact on us, we were still taking inbound stock but not able to trade.' (Participant 12, Chief Operations Officer, 32 years of experience)

'... because of the risk-adjusted strategy from government, we've seen different decisions made at different times and often at the drop of a hat. We either had lockdown level three or we had an altered state of lockdown level three. We've had different provinces at different levels. And, so, dealing with the legislative change has been quite disruptive... So, we've needed to interpret, communicate, negotiate with authorities in order to arrive at new standards and new protocols and new ways of sort of normalising our flow of goods.' (Participant 1, Head of Logistics and Supply Chain, 15 years of experience)

\section{Theme 2: Internal disruptions}

Theme 2, internal disruptions comprise all the disruptions the retailers experience within their internal supply chain. Pasanen (2015:13) described an internal supply chain as the chain of activities or functions within a single organisation that provides a product to the customer. In particular, three sub-themes were identified from the interview data, namely, capacity constraints of internal systems, operations and facilities ill-equipped to accommodate demand increases, and the inability to achieve service level agreements.

\section{Capacity constraints of internal systems}

Amongst the scholars who have investigated the impact of COVID-19 on supply chains, capacity constraints were identified as one of the biggest SCDs (Butt 2021; Ivanov 2021; Magableh 2021). In particular, the authors identified capacity constraints in terms of production, location, inventory, storage, planning, decision-making, visibility, liquidity and responsiveness. This study found that for the omnichannel retailers, demand increases from consumers strained frontend systems (such as the website's capacity) which spilt over into back-end systems:

'COVID taught us a lot of lessons and some of the lessons were we weren't as in control ... (I'm talking about kind of omnichannel retailing or the e-commerce side in particular). Our assets weren't as ready as we would have liked, particularly technology, and while we thought we were a customer-centric organisation it wasn't showing up in the efforts to fulfil e-commerce orders.' (Participant 6, VP of Supply Chain \& eCommerce Operations, 17 years of experience)

'It's exposed the weakness - once you start operating at the edge of your capability, things start to fall over. People start getting worn out, systems start to get to their operating limits, systems that were built for twenty thousand transactions a second suddenly having to cope with forty thousand transactions a second just fall over. The website that was built to comfortably handle two and a half thousand concurrent user sessions is now having to deal with five thousand concurrent user sessions. And that stuff, you can't build it overnight.' (Participant 16, Head of Online Operations, 30 years of experience)

\section{Far-reaching changes to standard operation procedures}

Standard operating procedures (SOPs) are a set of prescribed methods or step-by-step instructions compiled by an organisation to be followed routinely to achieve efficiency, quality output and uniformity of performance amongst workers of an organisation. In line with the findings of previous authors, the participants in this study indicated that substantial changes to their SOPs had to be implemented, which resulted in major disruptions to their regular operations. Firstly, as Mittal and Sinha (2021) found, retailers had to adhere to the government's strict social distancing and sanitation guidelines. This required new SOPs for store workers, warehouse employees, and in-store engagement with customers. Secondly, restrictions regarding operating hours and curfews meant that retailers had to cope with fewer employees whilst trying to scale operations to meet demand surges (Mollenkopf et al. 2021:194): 
'So, it did change quite a bit in terms of the SOP... there's a whole new SOP that exists with all the couriers where the vehicles get sanitised every night... also, they are having to split their workers. So, where they would normally work a normal seven to half past four day, they now have put in a night shift... so, they're trying to keep that social distancing. But you're definitely losing momentum. So, it really changed the operational aspect of life in terms of how we know it and how we staff.' (Participant 3, Head of Logistics and E-fulfilment, 25 years of experience)

\section{Inability to achieve service level agreements}

Central to the omnichannel retail proposition is effective and fast last-mile order fulfilment and delivery (Larke, Kilgour \& O'Connor 2018:469). Whilst service level agreements (SLAs) are primarily associated with buyer/supplier agreements, in omnichannel retailing, SLAs relate to delivery agreements between the omnichannel retailer and their customers, for example, expected delivery between 2-3 working days. Omnichannel shoppers are empowered and well-informed; they know the level of service they can expect from retailers (Murfield et al. 2017:263). These consumers expect retailers to meet and even exceed the SLAs they are accustomed to; however, during the pandemic, respondents indicated that they were unable to meet SLAs regular customers had come to expect of them:

\begin{abstract}
'You can have a great online experience in terms of ease of shop but if you have to wait seven days outside of your delivery SLA it becomes an irritation. So, the struggle has been delivering on the SLA in terms of product delivery. So, logistics has been a bit of an issue for us.' (Participant 7, Operations Business Development Manager, 23 years of experience)

'I think demand's obviously been a bit more than capacity, I think especially in the online space, that's a challenge. So, you end up with extended delivery times and SLAs not being achieved.' (Participant 17, Head of Supply Chain Optimisation, 13 years of experience)
\end{abstract}

\section{Theme 3: Response strategies}

Previous literature has exhaustively explored response strategies for SCDs, some of which have been addressed as part of the literature review for this article. However, these strategies usually advocate for relatively predictable SCDs; in the case of 'Black Swan events' such as the COVID-19 pandemic, most organisations do not have risk mitigating strategies in place that could simply be 'activated' once such a disruption occur (Wieland \& Durach 2021:1). As observed in the literature, resilience relates to the ability of an organisation to respond to SCDs. Several resilience capabilities were listed in Table 1. Based on the respondent's testimonies, it became clear that agility played a central role in their ability to respond to the pandemic's disruptions. Although agility was not assigned as a theme in itself, the centrality of agility in responding to the pandemic will become evident in the below discussion. Response strategies employed by the omnichannel retailers can be categorised into three subthemes, namely, retailer's ability to invest in new channels and processes, following a clear strategy for long-term planning, and retailer's strategic decision-making capabilities.

\section{Ability to invest in new channels and processes}

Developing omnichannel processes necessitates appropriate financial investments in human resources, physical and digital channels, mobile applications, social media platforms, advanced information technology and logistics services (Ürgüplü \& Hüseyinoğlu 2021). Considering the magnitude of the financial investment involved in developing omnichannel infrastructure, retailers plan these investments years in advance (Hajdas, Radomska \& Silva 2020:3). Kazancoglu and Demir (2021) found that investment in digital channels effectively mitigates the negative impact of the COVID-19 pandemic on retail supply chains. Their finding is supported by the participants from this study, who indicated that the ability to unlock investment to expand omnichannel services' capacity was a vital ingredient in their response to the pandemic. Investments in new channels and processes allowed the retailers to scale their online channel's capacity, alleviating external demand pressures and reducing pressures on internal systems. However, the key to this response strategy was speed (agility). Investment decisions had to be made unrestricted by organisational bureaucracy:

'... I think that ability to kinda think on your feet and adapt quickly, but also don't lose sight of the ability to invest. If the business has got the ability to turn on investment in a particular channel, so if it's got the cash reserves or the cashflow to be able to inject money quickly in a direction, that makes a huge different.' (Participant 16, Head of Online Operations, 30 years of experience)

'... in November nineteen, we presented our strategy to the Board and one of the items specifically then was around digital webstore and IT or technology ... we presented a five-year plan. And November twenty, a year later when we had a review, where are we? We were two years ahead of the plan, and that's just purely because of COVID. We couldn't wait for some of these things. We just really said, guys, you have to make this happen as quickly as possible, and that's one of the things that COVID did. It created more urgency to execute certain things a lot quicker.' (Participant 14, Chief Executive Officer, 30 years of experience)

\section{Following a clear strategy for long-term planning}

Reviewing and updating key supply chain risks are vital in the management and planning SCDs (Nascimento et al. 2021:89). However, in unforeseen events such as the COVID-19 pandemic, organisations often react knee-jerky. Whilst this may provide short-term interventions to mitigate the risk, it fails to address supply chain vulnerabilities in the long term (Butt 2021). Velayutham et al. (2021) debate that organisations that are genuinely focused on resilience will learn from the pandemic to plan and prepare for future SCDs. From the interviewees' testimonials, it was noticed that whilst the retailers have a long-term focus on addressing the pandemic, they struggled to strike a balance between mitigating the disruption whilst planning for the long-term. Whilst the demand for online services may have increased, scepticism still existed in terms of its longevity. The participants expressed that whilst they are optimistic about the growth of the omnichannel environment in South Africa, finance 
managers were still reluctant to make significant, long-term financial commitments to the online landscape:

\begin{abstract}
'... what it has done is it's forced us to look more critically at our longer-term planning whereas before we might have had a much sort of shallower horizon. We need to kinda say...if we were faced with this kind of thing again in three years' time, how would it look then and are we building big enough now for then? But at the same time, the kind of cautious sort of finance voice is saying don't spend too much on building muscle that you don't need. So, if you're gonna build bigger systems, try and keep it in balance.' (Participant 16, Head of Online Operations, 30 years of experience)
\end{abstract}

The respondents pointed out that one of their long-term approaches for reducing the disruption caused by the COVID-19 pandemic is moving some of their imported goods to local manufacturing. In contrast, multi-sourcing is often offered as a risk mediating strategy (Agigi et al. 2016:5; Pettit et al. 2010:12). Nevertheless, the pandemic caused significant disruptions to the global supply chain, occasioning retailers to re-evaluate their onshoring options. The interviewees did, however, point out that onshoring is only a resilient solution when it is accompanied by transformative changes in government policies that provide incentives for domestic production and sourcing:

'The other really positive impact that had come from it [COVID-19], I see a lot of retailers have started to really look aggressively at local sourcing ... And the Department of Trade is also working really hard to make it more cost-effective to do locally.' (Participant 10, Head of Africa Supply Chain, 20 years of experience)

'Retailers will pay a premium for certainty [and] there's no surprises on shipping costs or containers not being available, exchange rate changes, you name it, I'll pay a premium because it simplifies my retail model ... longer term, we know the rand is gonna collapse, we know it's gonna become more and more difficult to rely on imports.' (Participant 14, Chief Executive Officer, 30 years of experience)

\section{Strategic and fluent decision-making capabilities}

Selecting an appropriate reaction to SCDs requires a trade-off amongst different performance measures (Magableh 2021:15). Generally, this entails an evaluation of the related costs and gains expected from implementing each alternative reaction. Nel et al. (2018:2) add that planning and communication between relevant parties lead to agile decision-making in response to SCDs. Shared decision-making and open lines of communication were underscored by the participants from this study as important aspects in their response to the pandemic. Strategic and fluent decision-making capabilities constitute two issues. Firstly, retailers had to be unsentimental regarding their traditional operations. Many of the processes they have developed over the years were insufficient to handle the demand hikes coupled with the supply shortages. Secondly, retailers had to break down traditional reporting structures designated by multi-layered organisational hierarchies. The respondents demonstrated that flat organisational decision-making structures uncomplicated by organisational bureaucracy were imperative in their ability to respond to SCDs in real-time:

'And the key thing that made the difference here was that we had put together a small working group, we had a direct line to the CEO, the CEO gave us a mandate and said you will do this and you will do it as fast... under normal circumstances, the job that we did would have taken probably six to twelve months to execute. So, what does it take? It takes a very clear decisionmaking process, a very clear mandate, removing the barriers to implementation. And the way to do it is to shorten the decision chain... break down that hierarchy so that the distance between the decision maker and the execution is as narrow as possible.' (Participant 16, Head of Online Operations, 30 years of experience)

'We really focussed on the execution side and we made a couple of big calls. I guess that is the ability you aim for... to go and make decisions like that. So, the buck stops with me, I don't have to go and consult with too many people. I think that is one thing that we keep on fighting to say how do we keep that agility as an organisation?' (Participant 14, Chief Executive Officer, 30 years of experience)

'And it was incredibly valuable lessons in the sense that we were able to reflect and actually make some really hard decisions. Every day I was taking an axe to certain things that we thought that we were good at but weren't, and I was saying we're not doing it anymore, it's done, it's finished, it's over.' (Participant 6, VP of Supply Chain \& eCommerce Operations, 17 years of experience)

\section{Discussion \\ Outline of the results}

The purpose of this study was firstly to investigate the major SCDs omnichannel retailers in South Africa impacted by the COVID-19 pandemic (RQ1). Secondly, the study aimed to determine the response strategies omnichannel retailers employed to react to the SCDs (RQ2). In conclusion of the data analysis, RQ1 was answered by establishing that the SCDs could be classified as disruptions that either originated external to the organisations or internally. External disruptions originated from the sudden and drastic migration of consumers to online channels. Whilst the participants noted that the demand increase positively signalled the future growth potential of omnichannel retailing in South Africa, as it was accompanied by many challenges. Online channels reached their capacity, and the retailers were left unable to meet their omnichannel consumers' demand, which resulted in unsatisfied customers. The capacity constraints of supply chain partners were the second external SCD identified from the data. The retailers were unable to scale their internal operating ability because of the limited capacity of partners in terms of last-mile logistics and warehousing. Also, the participants pointed out that they had to renegotiate some of their supplier terms, to adapt to the changing operating environment. The final external disruption related to government regulations and lockdown restrictions. Respondents recounted the confusion caused by ill-defined regulations of restricted products. At the same time, retailers selling products with expiry dates highlighted the challenges of managing perishable product categories whilst attempting to mitigate spoilage and shrinkage issues. 
Internal disruptions originated from constraints in terms of the omnichannel retailers' internal systems. The participants pointed out that they were unprepared for the abrupt increase in demand for online channels, which severely strained their front-end operations and systems. The retailers underscored the disruption by the drastic and far-reaching changes they had to implement to their SOPs. Operational aspects such as vehicle sanitation and rotational rosters had to be carried out following the social distancing guidelines imposed by government. Finally, the retailers pointed out that the rise in demand for online services, coupled with the other internal and external disruptions they experienced, triggered their inability to meet delivery on SLAs long-time customers had become accustomed to.

In addition, this article aimed to identify the response strategies that omnichannel retailers employed to rapidly respond to the SCDs caused by the COVID-19 pandemic (RQ2). This study found that omnichannel retailers relied on three major response strategies in their effort to mitigate the SCDs caused by the COVID-19 pandemic. Firstly, participants stated that the ability to unlock investment to expand the online channel's capacity served as a major catalyst in response to SCDs. Through increased capacity, the retailers could better serve their expanding customer base and relieve pressure on internal systems. Following a clear strategy for long-term planning was another necessary response for retailers. The retailers considered a balance between future investment in capacity development for omnichannel infrastructure and the growth potential of online retailing in South Africa. In addition, onshoring options were considered as a way to alleviate the disruption caused by imports. Finally, the retailers expressed the importance of fluent and strategic decision-making capabilities to mitigate the impact of SCDs. Herein, the retailers expressed that they had to be impassive about long-standing organisational processes, and they had to be flexible and willing to make strategic changes. Finally, the retailers indicated that their agility and resilience were firmly rooted in simplifying and clarifying the decision chain. Following a clear mandate, uncomplicated by organisational bureaucracy, was instrumental in their swift response to the pandemic.

\section{Practical implications}

This study has meaningful implications for omnichannel retailing practitioners. Because the coronavirus is still a live threat and its impact on supply chains has not yet passed, omnichannel retailers can apply the findings of this study to firstly understand and identify the external and internal SCDs they are facing within the industry. Secondly, by taking the right actions, omnichannel retailers can turn the disruptions caused by the pandemic into meaningful change, starting with a consideration of the response strategies outlined in this article. These response strategies could guide retailers on what approach should be followed to become more resilient in the face of disruption. Furthermore, omnichannel retailers could use these findings to build risk identification and management frameworks in anticipation of potential future disruptions.

\section{Limitations and directions for future research}

This study has some limitations. Firstly, the pandemic is emerging and evolving. Therefore, whilst the pandemic is still ongoing, more thematic areas might be revealed, providing more insight into the impact of the disruption on omnichannel supply chains. Secondly, published literature on COVID-19 is sparse, limiting the possibilities for cross-validation and the transferability of findings. Finally, this study is limited because it considers the managerial perspectives of omnichannel retailers based only in one country, that is, South Africa. Future research should sample participants from other parts of the world to better understand if other retailers have employed similar response strategies to mitigate and respond to the disruptions caused by COVID-19. Other research opportunities include investigations into specific upstream and downstream disruptions experienced by omnichannel retailers and how supply networks have worked collaboratively to mitigate the disruptions caused by the pandemic. Large scale quantitative studies could also be beneficial to quantify the extent of each disruption identified in this research.

\section{Conclusion}

The COVID-19 pandemic is likely to result in long-lasting changes to the normal operations of global supply chains. Post-pandemic supply chains will need to be more resilient to serve their customers and clients. Although consumer reliance on digital shopping alternatives increased dramatically during the COVID-19 pandemic, this reliance could expand into a fundamental dependence on omnichannel shopping. Whilst the pandemic proved to be an opportunity for omnichannel retailers, the high demand and order congestions from the delays resulted in demand vulnerability and massive supply chain disruptions. To be competitive in future, retailers will need to build resilient supply chain operations. This study serves as a starting point to guide retailers in developing resilient omnichannel supply chain response strategies by highlighting possible external and internal disruptions. In doing so, this research revealed some of the lessons omnichannel retailers learnt during the pandemic and how an agile response to the pandemic led to supply chain resilience. Whilst the global pandemic will pass, 'Black Swan' events may become a regular occurrence in future. Those retailers who take the opportunity to learn from the pandemic and build more resilience into their supply chain operations will become the most competitive retailers in future.

\section{Acknowledgements}

The author would like to thank Prof. JA Badenhorst-Weiss and Ms. T. Grebe for comments made on earlier versions of the article.

\section{Competing interests}

The author declares that she has no financial or personal relationships, which may have inappropriately influenced her in writing this article. 


\section{Author's contribution}

The author declares she is the sole author of this research article.

\section{Funding information}

The author disclosed receipt of the following financial support for the research of this article: This work was supported by the academic qualification improvement programme of The University of South Africa.

\section{Data availability}

The data that support the findings of this study are available from the corresponding author, A.N.W., upon reasonable request.

\section{Disclaimer}

The views and opinions expressed in this article are those of the author and do not necessarily reflect the official policy or position of any affiliated agency of the author.

\section{References}

Adobor, H., 2019, 'Supply chain resilience: A multi-level framework', International Journal of Logistics Research and Applications 22(6), 533-556. https://doi.org/10. 1080/13675567.2018.1551483

Agigi, A., Niemann, W. \& Kotzé, T., 2016, 'Supply chain design approaches for supply chain resilience: A qualitative study of South African fast-moving consumer goods grocery manufacturers', Journal of Transport and Supply Chain Management 10(1), 1-15. https://doi.org/10.4102/jtscm.v10i1.253

Ali, M., Rahman, S.M. \& Frederico, G.F., 2021, 'Capability components of supply chain resilience for readymade garments (RMG) sector in Bangladesh during COVID-19', Modern Supply Chain Research and Applications 3(2), 127-144. https://doi. org/10.1108/MSCRA-06-2020-0015

Bairagi, V. \& Munot, M.V., 2019, Research methodology: A practical and scientific approach, Taylor \& Francis, New York, NY.

Bajpai, P., 2020, 'Why China is "the world's factory"', in Investopedia, viewed 08 July 2020, from https://www.investopedia.com/articles/investing/102214/why-chinaworlds-factory.asp.

Behdani, B., 2013, 'Handling disruptions in supply chains: An integrated framework and an agent-based model', Masters thesis, Sharif University of Technology, Tehran.

Bell, N., 2020, 'The changing face of supply chain', Bizcommunity, viewed 01 June 2021, from https://www.bizcommunity.com/Article/196/760/206197.html.

Braun, V. \& Clarke, V., 2006, 'Using thematic analysis in psychology', Qualitative ResearchinPsychology3(2),77-101.https://doi.org/10.1191/1478088706qp063oa

Braun, V. \& Clarke, V., 2021a, 'Can I use TA? Should I use TA? Should I not use TA? Comparing reflexive thematic analysis and other pattern-based qualitative analytic approaches', Counselling and Psychotherapy Research 21(1), 37-47. https://doi.org/10.1002/capr.12360

Braun, V. \& Clarke, V., 2021b, 'To saturate or not to saturate? Questioning data saturation as a useful concept for thematic analysis and sample-size rationales', Qualitative Research in Sport, Exercise and Health 13(2), 201-216. https://doi.org /10.1080/2159676X.2019.1704846

Bresler, A., 2020, 'E-commerce: Opening the economy, digitally', Bizcommunity, viewed 01 June 2021 from https://www.bizcommunity.com/Article/196/394/206185. html.

Butt, A.S., 2021, 'Strategies to mitigate the impact of COVID-19 on supply chain disruptions: A multiple case analysis of buyers and distributors', International Journal of Logistics Management, March, n.p. https://doi.org/10.1108/IJLM-112020-0455

Cassell, C., Cunliffe, A.L. \& Grandy, G., 2018, The SAGE handbook of qualitative business and management research methods, Sage, London.

Clarke, V. \& Braun, V., 2017, 'Thematic analysis', Journal of Positive Psychology 12(3), 297-298. https://doi.org/10.1080/17439760.2016.1262613

Coyne, I.T., 1997, 'Sampling in qualitative research. Purposeful and theoretical sampling; merging or clear boundaries?', Journal of Advanced Nursing 26(3), 623-630. https://doi.org/10.1046/j.1365-2648.1997.t01-25-00999.x

Craighead, C.W., Blackhurst, J., Rungtusanatham, M.J. \& Handfield, R.B., 2007, 'The severity of supply chain disruptions: Design characteristics and mitigation capabilities', Decision Sciences 38(1), 131-156. https://doi.org/10.1111/j.1540-5915.2007.00151.x
Creswell, J.W. \& Creswell, J., 2017, Research design qualitative, quantitative, and mixed methods approaches, 5th edn., Sage Publishing, Thousand Oaks, CA.

Deliotte, 2020, 'How COVID-19 has affected South African grocery retail consumer sentiment: Consumer insights pre-and during lockdown', Deloitte, viewed 05 June $2021 \mathrm{from}$ https://www2.deloitte.com/za/en/pages/consumer-industrial-products/ articles/covid-19-consumer-sentiment-in-retail.html.

Deloitte, 2020, 'Future consumer' series: Omnichannel transformation begins by grasping the key to consumer mentalities', Deloitte, viewed 10 June 2021, from https://www2.deloitte.com/cn/en/pages/strategy-operations/articles/ consumer-needs-2019-ncov.html.

Dohale, V., Ambilkar, P., Gunasekaran, A. \& Verma, P., 2021, 'Supply chain risk mitigation strategies during COVID-19: Exploratory cases of "make-to-order" handloom saree apparel industries', International Journal of Physical Distribution and Logistics Management, April, n.p. https://doi.org/10.1108/IJPDLM-12-2020-0450

Donadoni, M., Caniato, F. \& Cagliano, R., 2018, 'Linking product complexity, disruption and performance: The moderating role of supply chain resilience', Supply Chain Forum: An International Journal 19(4), 300-310. https://doi.org/10.1080/162583 12.2018.1551039

El Baz, J. \& Ruel, S., 2021 'Can supply chain risk management practices mitigate the disruption impacts on supply chains' resilience and robustness? Evidence from an empirical survey in a COVID-19 outbreak era', International Journal of Production Economics 233, 107972. https://doi.org/10.1016/j.ijpe.2020.107972

Etikan, I., Musa, S.A. \& Alkassim, R.S., 2016, 'Comparison of convenience sampling and purposive sampling', American Journal of Theoretical and Applied Statistics 5(1), 1-4. https://doi.org/10.11648/j.ajtas.20160501.11

Flynn, B., Cantor, D., Pagell, M., Dooley, K.J. \& Azadegan, A., 2021, 'From the editors: Introduction to managing supply chains beyond Covid-19- Preparing for the nex global mega-disruption', Journal of Supply Chain Management 57(1), 3-6. https:// doi.org/10.1111/jscm.12254

Francis, J.J., Johnston, M., Robertson, C., Glidewell, L., Entwistle, V., Eccles, M.P. et al., 2010 , 'What is an adequate sample size? Operationalising data saturation for theory-based interview studies', Psychology and Health 25(10), 1229-1245. https://doi.org/10.1080/08870440903194015

Frederico, G.F., 2021, 'Towards a supply chain 4.0 on the post-COVID-19 pandemic: A conceptual and strategic discussion for more resilient supply chains', Rajagir Management Journal, March, n.p. https://doi.org/10.1108/RAMJ-08-2020-0047

Free, C. \& Hecimovic, A., 2021, 'Global supply chains after COVID-19: The end of the road for neoliberal globalisation?', Accounting, Auditing and Accountability Journal 34(1), 58-84. https://doi.org/10.1108/AAAJ-06-2020-4634

Gunasekaran, A., Subramanian, N. \& Rahman, S., 2015, 'Supply chain resilience: Role of complexities and strategies', International Journal of Production Research 53(22), 6809-6819. https://doi.org/10.1080/00207543.2015.1093667

Haines, A., 2020, How COVID-19 will permanently change your omni-channel supply chain, Bastian Solutions, viewed 12 May 2021, from https://www.bastiansolutions. com/blog/how-covid-19-will-permanently-change-your-omni-channel-supplychain/.

Hajdas, M., Radomska, J. \& Silva, S.C., 2020, 'The omni-channel approach: A utopia for companies?', Journal of Retailing and Consumer Services, June, n.p. https://doi. org/10.1016/j.jretconser.2020.102131

Halan, D., 2021, 'E-tailers adaptation during early stages of "social distancing causing crises": An exploratory study' International Journal of Retail \& Distribution Management, June, n.p. https://doi.org/10.1108/JJRDM-11-2020-0475

Harland, C., 2021, 'Discontinuous wefts: Weaving a more interconnected supply chain management tapestry', Journal of Supply Chain Management 57(1), 27-40. https://doi.org/10.1111/jscm.12249

Hartzenberg, L., 2020, 'Covid-19 a shot in the arm for e-commerce', Bizcommunity, viewed25May2020, fromhttps://www.bizcommunity.com/Article/196/394/204333. html.

Holling, C.S., 1996, 'Engineering resilience versus ecological resilience', in Engineering within ecological constraints, pp. 31-43, National Academy Press, Washington, DC.

Hossain, T.M.T., Akterb, S., Kattiyapornponga, U. \& Dwivedic, Y., 2020 'Reconceptualizing integration quality dynamics for omnichannel marketing', Industrial Marketing Management 87, 225-241. https://doi.org/10.1016/j. indmarman.2019.12.006

Hosseini, S., Röglinger, M. \& Schmied, F., 2017, 'Omni-channel retail capabilities: An information systems perspective', in 38th International Conference on Information Systems, Seoul, December 10-13, 2017, pp. 1-19.

Hübner, A., Holzapfel, A. \& Kuhn, H., 2016, 'Distribution systems in omni-channel retailing', Business Research 9, 255-296. https://doi.org/10.1007/s40685-0160034-7

Hübner, A., Kuhn, H. \& Wollenburg, J., 2016, 'Last mile fulfilment and distribution in omni-channel grocery retailing: A strategic planning framework', Internationa Journal of Retail and Distribution Management 44(3), 228-247. https://doi. org/10.1108/IJRDM-11-2014-0154

Huré, E., Picot-Coupey, K. \& Ackermann, C.L., 2017, 'Understanding omni-channel shopping value: A mixed-method study', Journal of Retailing and Consumer 39 314-330. https://doi.org/10.1016/j.jretconser.2017.08.011

Ivanov, D., 2021, 'Lean resilience: AURA (Active Usage of Resilience Assets) framework for post-COVID-19 supply chain management', International Journal of Logistics Management, February, n.p. https://doi.org/10.1108/IJLM-11-2020-0448

Jain, V., Kumar, S., Soni, U. \& Chandra, C., 2017, 'Supply chain resilience: Model development and empirical analysis', International Journal of Production Research 55(22), 6779-6800. https://doi.org/10.1080/00207543.2017.1349947 
Juaneda-Ayensa, E., Mosquera, A. \& Murillo, Y.S., 2016, 'Omnichannel customer behavior: Key drivers of technology acceptance and use and their effects on purchase intention', Frontiers in Psychology 7, 1-11. https://doi.org/10.3389/fpsyg.2016.01117

Kazancoglu, I. \& Demir, B., 2021 'Analysing flow experience on repurchase intention in e-retailing during COVID-19', International Journal of Retail \& Distribution Management, May, n.p. https://doi.org/10.1108/IJRDM-10-2020-0429

Kembro, J.H., Norrman, A. \& Eriksson, E., 2018, 'Adapting warehouse operations and design to omni-channel logistics: A literature review and research agenda', International Journal of Physical Distribution \& Logistics Management 48(9) 890-912. https://doi.org/10.1108/IJPDLM-01-2017-0052

Ketchen, D.J. \& Craighead, C.W., 2021, 'Toward a theory of supply chain entrepreneurial embeddedness in disrupted and normal states', Journal of Supply Chain Management 57(1), 50-57. https://doi.org/10.1111/jscm.12251

Kourimsky, H. \& Van Den Berk, M., 2014, The impact of omni-channel commerce on supply chains, White Paper, Bielefeld, Germany, viewed 17 May 2021, from https://itelligencegroup.com/wp-content/usermedia/WhitePaper ImpactOfOmnichannel.pdf.

Lapan, S.D., Quartaroli, M.T. \& Riemer, F.J., 2012, Qualitative research: An introduction to methods and designs, John Wiley \& Sons, San Francisco, CA.

Larke, R., Kilgour, M. \& O'Connor, H., 2018, 'Build touchpoints and they will come: Transitioning to omnichannel retailing', International Journal of Physical Distribution \& Logistics Management 48(4), 465-483. https://doi.org/10.1108/ Distribution \& Logistics
IJPDLM-09-2016-0276

Lundberg, A., Nguyen, W. \& Esparza, C., 2019, 'The internationalization process of fashion retailers: A qualitative study investigating the use of exploitative and explorative dynamic capabilities when internationalizing a fashion ECC', Bachelors of Business Administration thesis, Department of Business Administration, of Business Administration
Jöning University, Sweden.

Macdonald, J.R., Zobel, C.W., Melnyk, A.S. \& Griffis, S.E., 2018, 'Supply chain risk and resilience: Theory building through structured experiments and simulation' International Journal of Production Research 56(12), 4337-4355. https://doi.org/ 10.1080/00207543.2017.1421787

Magableh, G.M., 2021, 'Supply chains and the COVID-19 pandemic: A comprehensive framework', European Management Review, February, n.p. https://doi.org/ 10.1111/emre.12449

Mahajan, K. \& Tomar, S., 2021, 'COVID-19 and supply chain disruption: Evidence from food markets in India', American Journal of Agricultural Economics 103(1), 35-52. https://doi.org/10.1111/ajae.12158

Marchet, G., Melacini, M., Perotti, S., Rasini, M. \& Tappia, E., 2018, 'Business logistics models in omni-channel: A classification framework and empirical analysis', International Journal of Physical Distribution \& Logistics Management 48(4), 439-464. https://doi.org/10.1108/IJPDLM-09-2016-0273

Messina, D., Barros, A.C. \& Matopoulos, A., 2020, 'An information management approach for supply chain disruption recovery', The International Journal of Logistics

Mirsch, T., Lehrer, C. \& Jung, R., 2016, 'Transitioning to an omnichannel approach: A dynamic capability perspective', in Thirty Seventh International Conference on Information Systems, Dublin, December 11-14, 2016, pp. 1-12.

Mittal, R. \& Sinha, P., 2021, 'Framework for a resilient religious tourism supply chain for mitigating post-pandemic risk', International Hospitality Review, May, n.p. https://doi.org/10.1108/IHR-09-2020-0053

Mollenkopf, D.A., Ozanne, L.K. \& Stolze, H.J., 2021, 'A transformative supply chain response to COVID-19', Journal of Service Management 32(2), 190-202. https:// doi.org/10.1108/JOSM-05-2020-0143

Murfield, M., Boone, C.A., Rutner, P. \& Thomas, R., 2017, 'Investigating logistics service quality in omni-channel retailing', International Journal of Physical Distribution \& Logistics Management 47(4), 263-296. https://doi.org/10.1108/ IJPDLM-06-2016-0161

Nascimento, A.P., Oliveira, M.P., Pettit, T.J. \& Bronzo, M., 2021, 'Practices and mechanisms for increasing supply chain resilience: The supply chain resilience sheaf', Continuity \& Resilience Review 3(1), 79-100. https://doi.org/10.1108/CRR-12-2020-0035

Negri, M., Cagno, E., Colicchia, C. \& Sarkis, J., 2021, 'Integrating sustainability and resilience in the supply chain: A systematic literature review and a research
agenda', Business Strategy and the Environment 2021, 1-29. https://doi. agenda', Business Strate
org/10.1002/bse. 2776

Nel, J., De Goede, E. \& Niemann, W., 2018, 'Supply chain disruptions: Insights from South African third-party logistics service providers and clients', Journal of
Transport and Supply Chain Management 12(0), 1-12. https://doi.org/10.4102/ jtscm.v12i0.377

Newstore, 2020, 'Omnichannel leadership report', Newestore, viewed 12 May 2021, from https://www.newstore.com/research-reports/.

Nielsen, 2020a, Covid-19 has flipped the value proposition of omnichannel shopping for constrained consumers, Nielsen, viewed 12 May 2021, from https://nielseniq. $\mathrm{com} / \mathrm{global} / \mathrm{en} / \mathrm{insights} / a n a l y s i s / 2020 / c o v i d-19$-has-flipped-the-valueproposition-of-omnichannel-shopping-for-constrained-consumers/.

Nielsen, 2020b, Overcoming online shopping obstacles amid lockdowns in Africa and the middle east is not only retailer driven, Nielsen, viewed 12 May 2021, from https://www.nielsen.com/ssa/en/insights/article/2020/overcomingonlineshopping-obstacles-amid-lockdowns-in-africa-and-the-middle-east-is-not-onlyretailer-driven/.

Novak, D.C., Wu, Z. \& Dooley, K.J., 2021, 'Whose resilience matters? Addressing issues of scale in supply chain resilience', Journal of Business Logistics 42(3), 1-13. https://doi.org/10.1111/jbl.12270

Pasanen, S., 2015, 'Internal supply chain: Process and performance measurement development', Masters thesis, Department of Business Informatics, Helsinki Metropolia University of Applied Sciences, Finland.
Patton, M.Q., 2018, 'Expert sampling', in B.B. Frey (eds.), The SAGE encyclopedia of educational research, measurement, and evaluation, pp. 648-649, Sage Publishing, Thousand Oaks, CA.

Paul, S.K. \& Chowdhury, P., 2020, 'Strategies for managing the impacts of disruptions during covid-19: An example of toilet paper', Global Journal of Flexible Systems Management 21(3), 283-293. https://doi.org/10.1007/s40171-020-00248-4

Peinkofer, S.T., Esper, T.L., Smith, R.J. \& Williams, B.D., 2019, 'Assessing the impact of drop-shipping fulfilment operations on the upstream supply chain', International Journal of Production Research 57(11), 3598-3621.

Pettit, T.J., Fiksel, J. \& Croxton, K.L., 2010, 'Ensuring supply chain resilience: Development of a conceptual framework', Journal of Business Logistics 31(1), 1-21. https://doi.org/10.1002/j.2158-1592.2010.tb00125.x

Picot-Coupey, K., Huré, E. \& Piveteau, L., 2016, 'Channel design to enrich customers' shopping experiences: Synchronizing clicks with bricks in an omni-channel perspective-the direct optic case', International Journal of Retail \& Distribution Management 44(3), 336-368. https://doi.org/10.1108/IJRDM-04-2015-0056

Ponomarov, S.Y. \& Holcomb, M.C., 2009, 'Understanding the concept of supply chain resilience', The International Journal of Logistics Management 20(1), 124-143. https://doi.org/10.1108/09574090910954873

Rai, H.B., Verlinde, S., Macharis, C., Schoutteet, P. \& Vanhaverbeke, L., 2019, 'Logistics outsourcing in omnichannel retail: State of practice and service recommendations', International Journal of Physical Distribution \& Logistics Management 49(3), 267-286. https://doi.org/10.1108/IJPDLM-02-2018-0092

Reyes, H.G. \& Giachetti, R., 2010, 'Using experts to develop a supply chain maturity model in Mexico', Supply Chain Management: An International Journal 15(6), 415-424. https://doi.org/10.1108/13598541011080400

Saghiri, S., Wilding, R., Mena, C. \& Bourlakis, M., 2017, 'Toward a three-dimensional framework for omni-channel', Journal of Business Research 77, 53-67. https://doi. org/10.1016/j.jbusres.2017.03.025

Sarkis, J., 2021, 'Supply chain sustainability: learning from the COVID-19 pandemic', International Journal of Operations and Production Management 41(1), 63-73. https://doi.org/10.1108/IJOPM-08-2020-0568

Saunders, M., Lewis, P. \& Thornhill, A., 2020, Research methods for business students, 8th edn., Pearson, Edinburgh.

Schambach, S., 2020, COVID-19 drives 3 key omnichannel capabilities, TotalRetail, viewed 03 June 2021, from https://www.mytotalretail.com/article/covid-19drives-3-key-omnichannel-capabilities/.

Schleper, M.C., Gold, S., Trautrims, A. \& Baldock, D., 2021, 'Pandemic-induced knowledge gaps in operations and supply chain management: COVID-19's impacts on retailing', International Journal of Operations and Production Management on retailing', International Journal of Operations and Productior
41(3), 193-205. https://doi.org/10.1108/IJOPM-12-2020-0837

Simba, S., Niemann, W. \& Agigi, A., 2013, 'Supply chain risk management processes for resilience: A study of South African grocery manufacturers', Journal of Transport and Supply Chain Management 11(0), 1-13. https://doi.org/10.4102/jtscm.v11i0.325

Snyman, A.N., 2014, 'Barriers and motivators to online grocery shopping in South Africa: A supply chain perspective', Masters thesis, Department of Business Management, University of South Africa.

Song, G., Song, S. \& Sun, L., 2019, 'Supply chain integration in omni-channel retailing: A logistics perspective', International Journal of Logistics Management 30(2), 527-548.

Taleb, N.N., 2007, The black swan: The impact of the highly improbable, Penguin, London.

The Institute for Supply Management, 2021, Impact of the coronavirus on the global supply chain: Round 2 research findings, The Institute for Supply Chain Management, viewed 13 June 2021, from https://www.ismworld.org/globalassets/pub/researchand-surveys/pdf/covid-19-round-4-research-impact-to-supply-chainpdf.

Thompson, D.D.P. \& Anderson, R., 2021, 'The COVID-19 response: Considerations for future humanitarian supply chain and logistics management research', Journal of Humanitarian Logistics and Supply Chain Management 11(2), 157-175. https:// doi.org/10.1108/JHLSCM-01-2021-0006

Tukamuhabwa, B.R., Stevenson, M., Busby J. \& Zorzini, M., 2015, 'Supply chain resilience: Definition, review and theoretical foundations for further study' International Journal of Production Research 53(18), 5592-5623. https://doi.org/ 10.1080/00207543.2015.1037934

Tustin, D.H., Ligthelm, A., Martins, J.H. \& Van Wyk, J., 2005, Marketing research in practice, Unisa Press, Pretoria.

Ürgüplü, Ö. \& Hüseyinoğlu, I.Ö.Y., 2021, 'The mediating effect of consumer empowerment in omni-channel retailing', International Journal of Retail \& Distribution Management, April, n.p. https://doi.org/10.1108/JJRDM-10-2020-0403

Van Hoek, R., 2020, 'Research opportunities for a more resilient post-COVID-19 supply chain - Closing the gap between research findings and industry practice', International Journal of Operations and Production Management 40(4), 341-355. https://doi.org/10.1108/IJOPM-03-2020-0165

Velayutham, A., Rahman, A.R., Narayan, A. \& Wang, M., 2021, 'Pandemic turned into pandemonium: The effect on supply chains and the role of accounting information', Accounting, Auditing \& Accountability Journal 34(6), 1404-1415. https://doi.org/10.1108/AAAJ-08-2020-4800

Vermeulen, J., Niemann, W. \& Kotzé, T., 2019, 'Exploring supply chain resilience in the South African telecommunications industry', Journal of Contemporary Management 16(2), 331-360. https://doi.org/10.35683/jcm19064.38

Weber, A.N. \& Badenhorst-Weiss, J.A., 2016, 'Time-based competition as a competitive strategy for online grocery retailers', Journal of Contemporary Management 13(1), 433-460. 
Weber, A.N. \& Badenhorst-Weiss, J., 2018, 'The last-mile logistical challenges of an omnichannel grocery retailer: A South African perspective', Journal of Transport and Supply Chain Management 12, 1-13. https://doi.org/10.4102/jtscm.v12i0.398

Wieland, A., 2021, 'Dancing the supply chain: Toward transformative supply chain management', Journal of Supply Chain Management 57(1), 58-73. https://doi. org/10.1111/jscm.12248

Wieland, A. \& Durach, C.F., 2021, 'Two perspectives on supply chain resilience', Journal of Business Logistics 42(3), 315-322.

World Health Organization, 2020, WHO director-general's statement on ihr emergency committee on novel coronavirus (2019-nCoV), World Health Organization, viewed 12 May 2021, from https://www.who.int/director-general/speeches/detail/whodirector-general-s-statement-on-ihr-emergency-committee-on-novelcoronavirus-(2019-ncov).
World Wide Worx, 2021, Online retail in South Africa leaps to R30-billion, World Wide Worx, viewed 13 June 2021, from http://www.worldwideworx.com/online-retailin-sa-2021/.

Ye, Y., Lau, H.K. \& Teo, L.K.Y., 2018, 'Drivers and barriers of omni-channel retailing in China: A case study of the fashion and apparel industry', International Journal of Retail and Distribution Management 46(7), 391-414. https://doi.org/10.1108/ IJRDM-04-2017-0062

Zhang, M., Ren, C., Wang, G.A. \& He, Z., 2018, 'The impact of channel integration on consumer responses in omni-channel retailing: The mediating effect of consumer empowerment', Electronic Commerce Research and Applications 28, 181-193. https://doi.org/10.1016/j.elerap.2018.02.002

Zikmund, W.G., Carr, J.C., Babin, B. \& Griffin, M., 2013, Business research methods, 9th edn., Cengage Publishing, Mason, $\mathrm{HO}$. 